\title{
Fate of water pumped from underground and contributions to sea-level rise
}

\author{
Yoshihide Wada ${ }^{1,2,3,4 \star}$, Min-Hui Lo ${ }^{5 \star}$, Pat J.-F. Yeh ${ }^{6}$, John T. Reager ${ }^{7}$, James S. Famiglietti ${ }^{7,8}$, \\ Ren-Jie $\mathrm{Wu}^{5}$ and $\mathrm{Yu}$-Heng Tseng ${ }^{9}$
}

The contributions from terrestrial water sources to sea-level rise, other than ice caps and glaciers, are highly uncertain and heavily debated ${ }^{1-5}$. Recent assessments indicate that groundwater depletion (GWD) may become the most important positive terrestrial contribution ${ }^{6-10}$ over the next 50 years, probably equal in magnitude to the current contributions from glaciers and ice caps $^{6}$. However, the existing estimates assume that nearly $100 \%$ of groundwater extracted eventually ends up in the oceans. Owing to limited knowledge of the pathways and mechanisms governing the ultimate fate of pumped groundwater, the relative fraction of global GWD that contributes to sea-level rise remains unknown. Here, using a coupled climate-hydrological model $\left.\right|^{11,12}$ simulation, we show that only $\mathbf{8 0} \%$ of GWD ends up in the ocean. An increase in runoff to the ocean accounts for roughly two-thirds, whereas the remainder results from the enhanced net flux of precipitation minus evaporation over the ocean, due to increased atmospheric vapour transport from the land to the ocean. The contribution of GWD to global sea-level rise amounted to $0.02( \pm 0.004) \mathrm{mm} \mathrm{yr}^{-1}$ in 1900 and increased to $0.27( \pm 0.04) \mathrm{mm} \mathrm{yr}^{-1}$ in 2000. This indicates that existing studies have substantially overestimated the contribution of GWD to global sea-level rise by a cumulative amount of at least $\mathbf{1 0} \mathbf{~ m m}$ during the twentieth century and early twenty-first century. With other terrestrial water contributions included, we estimate the net terrestrial water contribution during the period 1993-2010 to be +0.12 ( \pm 0.04$) \mathrm{mm} \mathrm{yr}^{-1}$, suggesting that the net terrestrial water contribution reported in the IPCC Fifth Assessment Report report is probably overestimated by a factor of three.

Sea-level rise (SLR) is a direct effect of climate change, through the thermal expansion of ocean waters and the contribution of melt water from ice sheets, ice caps and glaciers. In an initial assessment ${ }^{13}$, the net contribution of sub-polar terrestrial water storage change to global sea-level variation was highly uncertain and heavily debated $^{14-18}$. Terrestrial water contribution to sea-level variation includes the filling (due to impoundments) and sedimentation of dams, groundwater depletion, drainage of endorheic lakes and wetlands, deforestation, and changes in natural water stores (soil moisture, groundwater, permafrost and snow $)^{1,2,19,20}$. In the IPCC Fourth Assessment Report (IPCC AR4) ${ }^{3}$, the contribution of nonfrozen terrestrial waters to sea-level variation is not included owing to limited knowledge and the assumption that the negative contributions, such as the filling of dams, would compensate the positive contributions, mainly from GWD.

GWD, that is, the extraction of groundwater reserves at rates greater than its replenishment, can result in a positive contribution to SLR due to the net transfer of dormant fossil groundwater to the active hydrological cycle, and eventually to oceans. Lacking in situ groundwater-level observations increases the uncertainty in estimating GWD for many parts of the world. One of the earliest studies ${ }^{13}$ estimated a global GWD of $86.7 \mathrm{~km}^{3} \mathrm{yr}^{-1}$, which contributes $0.24 \mathrm{~mm} \mathrm{yr}^{-1}$ to SLR. Another study ${ }^{17}$ indicated that global GWD can contribute $0.10-0.30 \mathrm{~mm} \mathrm{yr}^{-1}$ to SLR. A regional study ${ }^{21}$ of the Middle East and North Africa estimated a rate of GWD of $26.8 \mathrm{~km}^{3} \mathrm{yr}^{-1}$, equivalent to $0.075 \mathrm{~mm} \mathrm{yr}^{-1}$ of SLR. Although these studies have evaluated direct groundwater storage changes, they have covered only limited global regions and do not account for some of the large aquifer systems where intensive groundwater mining has been well known (for example, Indo-Gangetic Plain and North China Plain) $)^{22}$.

More recently, using a global hydrological model, one study ${ }^{6}$ estimated the global GWD rate for 2000 to be $283( \pm 40) \mathrm{km}^{3} \mathrm{yr}^{-1}$ $\left(0.8 \pm 0.1 \mathrm{~mm} \mathrm{yr}^{-1}\right)$, responsible for $25( \pm 3) \%$ of recently observed $\mathrm{SLR}^{3}$. Later, the same authors revised their estimate ${ }^{7}$ by introducing a multiplicative correction factor to the original estimates ${ }^{6}$ for nonarid areas where the increased capture may be significant. The results showed that, during the 20th century, the GWD contribution to global sea level has increased from $0.035( \pm 0.009) \mathrm{mm} \mathrm{yr}^{-1}$ in 1900 to $0.1( \pm 0.03) \mathrm{mm} \mathrm{yr}^{-1}$ in 1950 , reaching $0.57( \pm 0.09) \mathrm{mm} \mathrm{yr}^{-1}$ in 2000. The flux-based method ${ }^{6,7}$, using only groundwater pumping and recharge fluxes, however, tends to overestimate GWD as it does not account for the increased capture due to decreased groundwater discharge and enhanced recharge from surface waters due to change in groundwater level. The method also ignores the compensating effects of pumping in other hydrologic fluxes, such as groundwater recharge and discharge, and as such does not represent a net contribution to SLR. Alternatively, a volumebased study ${ }^{8}$ estimated a smaller global GWD of $145( \pm 39) \mathrm{km}^{3} \mathrm{yr}^{-1}$ $\left(0.41 \pm 0.1 \mathrm{~mm} \mathrm{yr}^{-1}\right)$ during 2000-2008. This method used direct evidence of groundwater storage changes from in situ groundwater-level observations, calibrated groundwater modelling and GRACE satellite-based water storage data ${ }^{23-25}$ to calculate GWD $\left(101.6 \mathrm{~km}^{3} \mathrm{yr}^{-1} ; 0.29 \mathrm{~mm} \mathrm{yr}^{-1}\right)$ for the USA and five other major aquifer systems of the world (north India, North China Plain,

\footnotetext{
${ }^{1}$ NASA Goddard Institute for Space Studies, New York, New York 10025, USA. ${ }^{2}$ Center for Climate Systems Research, Columbia University, New York, New York 10025, USA. ${ }^{3}$ Department of Physical Geography, Utrecht University, 3584 CS Utrecht, The Netherlands. ${ }^{4}$ International Institute for Applied Systems Analysis, A-2361 Laxenburg, Austria. ${ }^{5}$ Department of Atmospheric Sciences, National Taiwan University, Taipei 10617, Taiwan. ${ }^{6}$ Department of Civil and Environmental Engineering, National University of Singapore, Singapore 117576, Singapore. ${ }^{7}$ NASA Jet Propulsion Laboratory, California Institute of Technology, Pasadena, California 91109, USA. ${ }^{8}$ Department of Earth System Science, Department of Civil and Environmental Engineering, University of California, Irvine, California 92697, USA. ${ }^{9}$ National Center for Atmospheric Research, Boulder, Colorado 80305, USA. *e-mail: y.wada@uu.nl;

minhuilo@ntu.edu.tw
} 

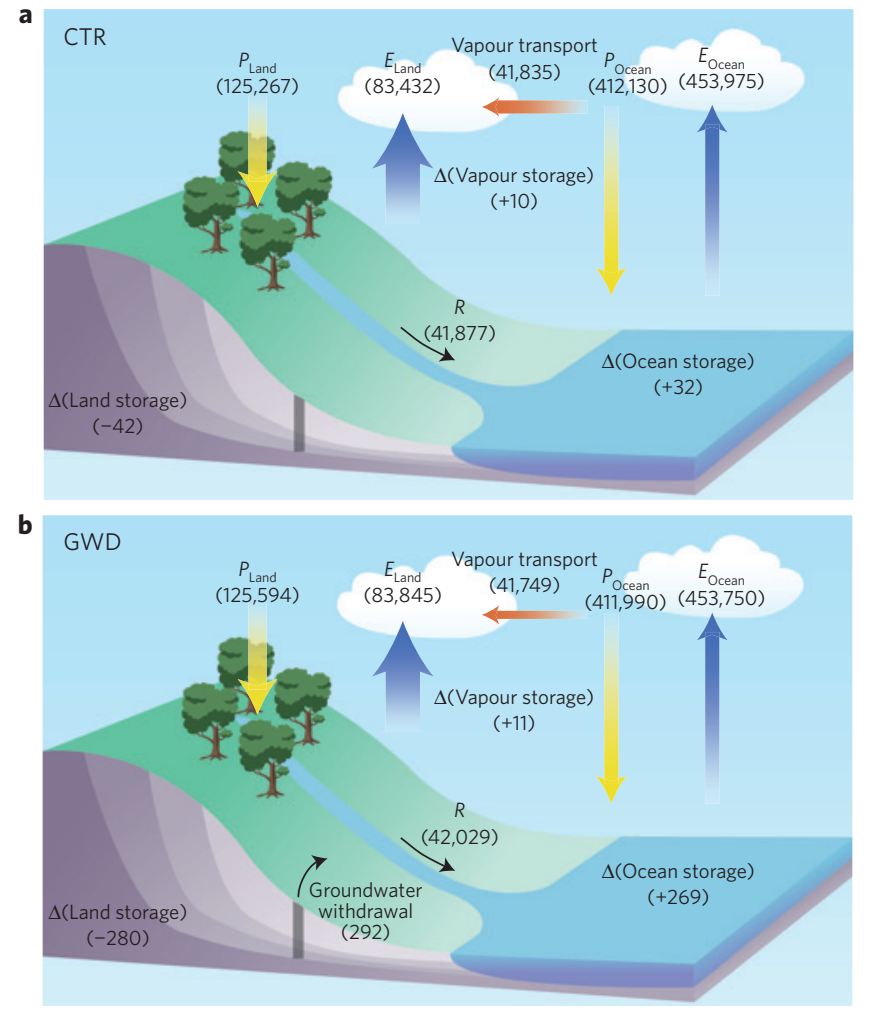

Figure 1 | Schematic diagram of global water budget over the land and the ocean. $\mathbf{a}, \mathbf{b}$, The values (in $\mathrm{km}^{3} \mathrm{yr}^{-1}$ ) show the long-term averages for a control (CTR) or natural run without pumping (a) and a GWD run with pumping (b) over the period 1900-1999 (see also Table 1).

Saudi Arabia, Nubian and Sahara). By assuming a constant ratio of depletion to abstraction (15.4\%), the GWD estimate of the USA was extrapolated to the rest of the world $\left(43.7 \mathrm{~km}^{3} \mathrm{yr}^{-1} ; 0.12 \mathrm{~mm} \mathrm{yr}^{-1}\right)$. Thus, this volume-based estimate does not account for regional variability in the relationship between GWD and abstraction ${ }^{26}$ worldwide, and can be applied only to limited global regions and aquifers where the estimates can be verified by observed well data.

Combining hydrological modelling with information from well observations and GRACE satellites, one study ${ }^{9}$ found a rapid increase in global GWD after 1960 and estimated the global GWD contribution to SLR to be $0.31 \mathrm{~mm} \mathrm{yr}^{-1}$ during 2000-2009. Another study ${ }^{10}$ used an integrated water resources assessment model to estimate the sea-level change caused by all changes in terrestrial water storage (mainly GWD and reservoir impoundment). However, their estimate is likely to overestimate the contribution of terrestrial water storage to SLR, because the model used did not account for any physical constraints on the amount of pumping. Instead, all water demands in excess of surface water availability are assumed to be unsustainable, and therefore satisfied by GWD $\left(1.05 \mathrm{~mm} \mathrm{yr}^{-1}\right)$.

The previous work suggests that a rapid increase in the contribution of GWD to SLR has occurred in recent decades $\left(0.31-0.57 \mathrm{~mm} \mathrm{yr}^{-1}\right)^{7-9}$. An increasing contribution from land waters to SLR is in fact noted in the IPCC Fifth Assessment Report (IPCC AR5) ${ }^{4}$; however, the uncertainty remains substantially large. Critical assumptions implicitly made in the IPCC AR5 report include that most of the groundwater extracted from aquifers ultimately ends up in the ocean, partly through runoff and partly, as most pumped groundwater is for irrigation use, through evapotranspiration and then precipitation, and that nearly $100 \%$ of the depleted groundwater ends up in the ocean, assuming all other stores (atmospheric moisture, surface waters, soil moisture and groundwater) remain constant ${ }^{6,7}$.

Owing to limited knowledge on the pathways and mechanisms by which the pumped groundwater is transported to the ocean, the relative fraction of the total GWD contributing to SLR remains unknown, and many studies continue to assume that all depleted groundwater eventually goes to the ocean. These previous estimates are based on offline model simulation, using uncoupled land hydrological simulation only. Thus, they did not take into account land-atmospheric-ocean feedback, such that it was assumed that all depleted groundwater would end up in the ocean. However, recent studies ${ }^{27-29}$ indicate that the irrigation water supply from groundwater and surface water enhance regional precipitation owing to the increased soil moisture and evaporation over the downwind regions. This warrants re-appraisal of the contribution of GWD to SLR for the validation of the critical assumptions in the IPCC AR5 report as mentioned above.

Here we present a coupled climate-hydrological model simulation result to show the relative contribution of GWD to global SLR for the 20th century. We used a state-of-the-art global climate model, the National Center for Atmospheric Research Community Earth System Model (CESM) ${ }^{11}$, to simulate the fate of water pumped from underground. Two fully coupled (atmosphereland-ocean-ice) experiments with CESM were conducted: the first is a control (CTR) run without groundwater pumping and the second is a GWD run with groundwater pumping. In the GWD run, an anthropogenic groundwater pumping flux is activated

Table 1 | Global mean annual water budget over the land and ocean for the period 1900-1999 in $\mathrm{km}^{3} \mathrm{yr}^{-1}$.

\begin{tabular}{|c|c|c|c|c|c|c|}
\hline & Precipitation $(P)$ & Runoff $(R)$ & Evaporation (E) & $\begin{array}{l}\text { Total storage } \\
\text { change }(\Delta S)\end{array}$ & $\begin{array}{l}\text { Precipitation minus } \\
\text { evaporation }\end{array}$ & $\begin{array}{l}\text { Atmospheric water } \\
\text { vapour change }\end{array}$ \\
\hline Land & & & & $P-R-E$ & $P-E$ & \\
\hline (1) GWD & 125,594 & 42,029 & 83,845 & -280 & 41,749 & - \\
\hline (2) CTR & 125,267 & 41,877 & 83,432 & -42 & 41,835 & - \\
\hline (3) GWD-CTR & +327 & +152 & +413 & -238 & -86 & - \\
\hline Ocean & & & & $P+R-E$ & $P-E$ & - \\
\hline (1) GWD & 411,990 & 42,029 & 453,750 & +269 & $-41,760$ & - \\
\hline (2) CTR & 412,130 & 41,877 & 453,975 & +32 & $-41,845$ & - \\
\hline (3) GWD-CTR & -140 & +152 & -225 & +237 & +85 & - \\
\hline \multicolumn{7}{|l|}{ Global } \\
\hline (1) GWD & - & - & - & - & - & +11 \\
\hline (2) CTR & - & - & - & - & - & +10 \\
\hline
\end{tabular}

These estimates are calculated from: (1) a GWD run with groundwater pumping, (2) a CTR run without groundwater pumping, and (3) the differences in budget components between the two runs (GWD-CTR). Mean global groundwater withdrawal in the GWD run is $292 \mathrm{~km}^{3} \mathrm{yr}^{-1}$ (notice that there are small rounding and numerical errors of $\pm 2-3 \mathrm{~km}^{3} \mathrm{yr}^{-1}$ after $100-\mathrm{year}$ integration of the land and ocean water budgets). 


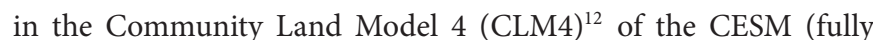
coupled). For the GWD estimates, we combined model estimates ${ }^{7}$ and previously published results ${ }^{7,8,22}$ (approximately $120 \mathrm{~km}^{3}$ for the year 2000). We refer to Methods for the detailed descriptions of the modelling framework, associated model physics, model performance and the calculation of the GWD estimates. Discussion on model uncertainty is given in the Supplementary Information.

We eventually estimated the pathways of water transport that originated from groundwater pumping. We calculated the portion of globally pumped groundwater amount resulting in simulated sea-level changes by integrating model estimates of oceanic precipitation $\left(P_{\text {Ocean }}\right)$, ocean evaporation $\left(E_{\text {Ocean }}\right)$, and runoff $\left(R_{\text {Land }}\right)$ from the ocean water budget (that is, ocean mass change $=$ ocean precipitation plus runoff from the land minus ocean evaporation, see equation (1)) over the period 1900-1999 (Fig. 1) (see Methods and Supplementary Information for the detailed water budgets of the land and ocean).

$$
\begin{gathered}
\Delta S_{\text {Ocean }}=P_{\text {Ocean }}+R_{\text {Land }}-E_{\text {Ocean }} \\
\Delta S_{\text {Land }}=P_{\text {Land }}-E_{\text {Land }}-R_{\text {Land }}
\end{gathered}
$$

It should be noted that groundwater pumping includes both renewable (groundwater recharge) and non-renewable groundwater (pumping in excess of recharge or GWD). It is the latter that ends up in the ocean and eventually contributes to SLR.

Our results show that the relative fraction of GWD amount that ends up in the ocean is $\sim 80 \%$, considerably lower than the previously assumed fraction of nearly $100 \%$ used in the IPCC AR5 report. Among the $80 \%$ of GWD contributing to SLR, around two-thirds come from an increase in runoff to the ocean from the land, whereas the rest (one-third) results from enhanced net flux of precipitation minus evaporation over the ocean due to excess atmospheric moisture transported from the land. The excess moisture, primarily due to irrigation over the land, is balanced by the increased water vapour transport from the land to the ocean (Fig. 1). Therefore, the atmosphere above the ocean receives more moisture, which reduces the water vapour deficit and hence ocean evaporation. As a result, locally recycled ocean precipitation gets suppressed, but to a lesser extent than ocean evaporation because the increased water vapour blowing from land to ocean possibly increases advective ocean precipitation

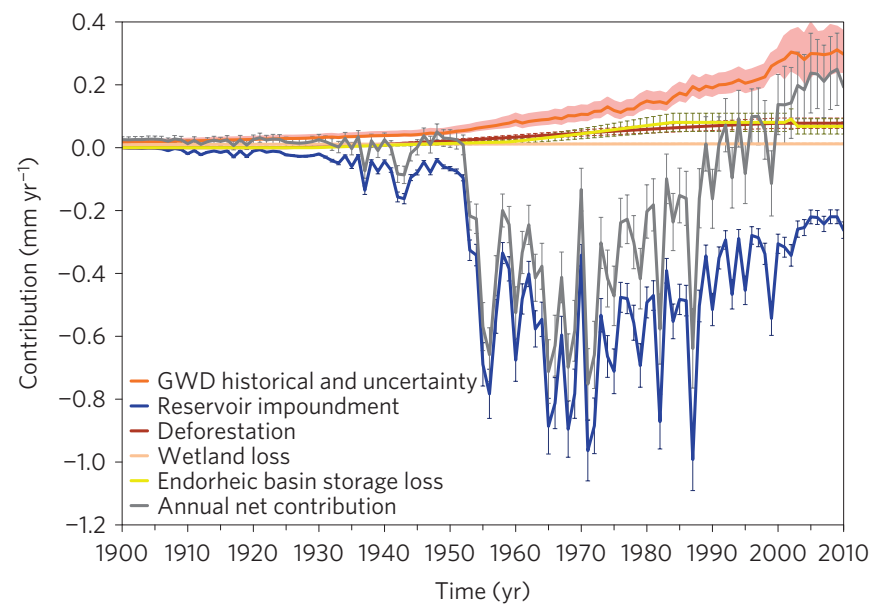

Figure 2 | Time series of the estimated annual contribution of terrestrial water storage change to global sea level over the period 1900-2010. To estimate the mean and standard deviation over the groundwater depletion estimates, we used the mean and standard deviation from groundwater recharge and pumping as parameters in an assumed Gaussian distribution and drew 100 realizations for each flux ${ }^{6,7}$ (see Methods). We subsequently calculated the mean (coloured curves) and standard deviation (error bars) from 10,000 realizations. The GWD total uncertainty band (light red) was taken from maximum and minimum uncertainty ranges of past estimates (1900-2010) for each year. The model simulation of this study was done for the period 1900-1999, but using the estimated fraction (80\%) of GWD to SLR we also estimated the terrestrial water storage change to global sea level over the period 2000-2010.

(Table 1). Approximately $\sim 20 \%$ of the pumped GWD remains on the land, eventually returning back to soil and groundwater storage as infiltration and recharge from precipitation through regional and local atmospheric circulations (evapotranspiration and then precipitation), and irrigation (evapotranspiration and then precipitation and irrigation water supply).

Using this fraction (80\%), we found that the past contribution of GWD to global SLR has been substantially overestimated. During the 20th century and early 21 st century, a cumulative amount of at least $10 \mathrm{~mm}$ should be deducted from the

Table 2 | Global sea-level budget from IPCC AR5 ${ }^{4}$ compared with the estimate of this study for the land water storage over the two

\begin{tabular}{|c|c|c|c|}
\hline Component & Comparison & $1971-2010\left(\mathrm{~mm} \mathrm{yr}^{-1}\right)$ & $1993-2010\left(\mathrm{~mm} \mathrm{yr}^{-1}\right)$ \\
\hline Observed SLR & & $2.0( \pm 0.3)$ & $3.2( \pm 0.4)$ \\
\hline \multicolumn{4}{|l|}{ Observed } \\
\hline Thermal expansion & & $0.8( \pm 0.3)$ & $1.1( \pm 0.3)$ \\
\hline Glaciers except in Greenland and Antarctica & & $0.62( \pm 0.37)$ & $0.76( \pm 0.37)$ \\
\hline Glaciers in Greenland & & $0.06( \pm 0.03)$ & $0.10( \pm 0.03)$ \\
\hline Greenland ice sheet & & & $0.33( \pm 0.08)$ \\
\hline Antarctica ice sheet & & & $0.27( \pm 0.12)$ \\
\hline \multicolumn{4}{|l|}{ Modelled } \\
\hline Thermal expansion & & $0.96( \pm 0.45)$ & $1.49( \pm 0.53)$ \\
\hline Glaciers except in Greenland and Antarctica & & $0.62( \pm 0.22)$ & $0.78( \pm 0.35)$ \\
\hline Glaciers in Greenland & & $0.10( \pm 0.05)$ & $0.14( \pm 0.09)$ \\
\hline \multirow[t]{2}{*}{ Land water storage } & IPCC AR5 & $0.12( \pm 0.09)$ & $0.38( \pm 0.12)$ \\
\hline & This study & $-0.10( \pm 0.03)$ & $0.12( \pm 0.04)$ \\
\hline \multirow[t]{2}{*}{ Total including land water storage } & IPCC AR5 & $1.8( \pm 0.5)$ & $2.8( \pm 0.7)$ \\
\hline & This study & $1.58( \pm 0.4)$ & $2.53( \pm 0.6)$ \\
\hline \multirow[t]{2}{*}{ Residual } & IPCC AR5 & $0.2( \pm 0.6)$ & $0.4( \pm 0.8)$ \\
\hline & This study & $0.42( \pm 0.6)$ & $0.67( \pm 0.8)$ \\
\hline
\end{tabular}
different time intervals (1971-2010 and 1993-2010). 
current estimate of land water contributions to global SLR over time.

Our results show that the contribution of GWD to sea level increased from $+0.02( \pm 0.004) \mathrm{mm} \mathrm{yr}^{-1}$ in 1900 to +0.27 $( \pm 0.04) \mathrm{mm} \mathrm{yr}^{-1}$ in 2000 (Fig. 2). The average contribution of GWD to SLR is $+0.30( \pm 0.05) \mathrm{mm} \mathrm{yr}^{-1}$ during the period $2000-2010$. In addition to GWD, we include impoundment by dam building ${ }^{7,30}$, deforestation ${ }^{7}$, wetland loss ${ }^{7}$ and storage change in endorheic basins and lakes ${ }^{7,13}$ (see Methods). When placing our revised contribution of GWD to SLR in context with other anthropogenic terrestrial sources $^{7,13,30}$, the net contribution of non-natural terrestrial sources (that is, groundwater and dam impoundment) is a negligible order of magnitude $+0.01( \pm 0.004) \mathrm{mm} \mathrm{yr}^{-1}$ over the period $1990-2000$ as a result of dam impoundment ${ }^{30}$. The net anthropogenic contribution eventually becomes positive to the order of magnitude $+0.2( \pm 0.07) \mathrm{mm} \mathrm{yr}^{-1}$ only after the recent period 2000-2010 owing to increased GWD and decreased dam building. During the period 1993-2010 we calculate the net terrestrial contribution to SLR as being $+0.12( \pm 0.04) \mathrm{mm} \mathrm{yr}^{-1}$. This suggests that the result presented in recent IPCC AR5, which indicated a much larger contribution of $0.38 \mathrm{~mm} \mathrm{yr}^{-1}$, is probably overestimated by a factor of three (Table 2).

\section{Methods}

Methods and any associated references are available in the online version of the paper.

\section{References}

1. Church, J. A. et al. Revisiting the Earth's sea-level and energy budgets from 1961 to 2008. Geophys. Res. Lett. 38, L18601 (2011).

2. Gregory, J. M. et al. Twentieth-century global-mean sea level rise: is the whole greater than the sum of the parts? J. Clim. 26, 4476-4499 (2013).

3. IPCC Climate Change 2007: The Physical Science Basis (eds Solomon, S. et al.) (Cambridge Univ. Press, 2007).

4. Church, J. A. et al. in Climate Change 2013: The Physical Science Basis (eds Stocker, T. F. et al.) 1137-1216 (IPCC, Cambridge Univ. Press, 2013).

5. Milly, P. C. D. et al. in Understanding Sea-Level Rise and Variability (eds Church, J. A. et al.) Ch. 8 (Wiley-Blackwell, 2010)

6. Wada, Y. et al. Global depletion of groundwater resources. Geophys. Res. Lett. 37, L20402 (2010).

7. Wada, Y. et al. Past and future contribution of global groundwater depletion to sea-level rise. Geophys. Res. Lett. 39, L09402 (2012).

8. Konikow, L. F. Contribution of global groundwater depletion since 1900 to sea-level rise. Geophys. Res. Lett. 38, L17401 (2011).

9. Döll, P. et al. Global-scale assessment of groundwater depletion and related groundwater abstractions: combining hydrological modeling with information from well observations and GRACE satellites. Wat. Resour. Res. 50, 5698-5720 (2014).

10. Pokhrel, Y. N. et al. Model estimates of sea level change due to anthropogenic impacts on terrestrial water storage. Nature Geosci. 5, 389-392 (2012).

11. Hurrell, J. W. et al. The community earth system model: a framework for collaborative research. Bull. Am. Meteorol. Soc. 94, 1339-1360 (2013).

12. Lawrence, D. M. et al. Parameterization improvements and functional and structural advances in Version 4 of the Community Land Model. J. Adv. Model. Earth Syst. 3, M03001 (2011).
13. Sahagian, D. L., Schwartz, F. W. \& Jacobs, D. K. Direct anthropogenic contributions to sea level rise in the twentieth century. Nature 367, 54-57 (1994).

14. Greuell, W. Sea-level rise. Nature 369, 615-616 (1994).

15. Chao, B. F. Man-made lakes and sea-level rise. Nature 370, 258 (1994).

16. Rodenburg, E. Man-made lakes and sea-level rise. Nature 370, 258 (1994).

17. Gornitz, V., Rosenzeig, C. \& Hillel, D. Is sea level rising or falling? Nature 371, 481 (1994).

18. Sahagian, D. L., Schwartz, F. W. \& Jacobs, D. K. Sea-level rise reply. Nature 369, 616 (1994).

19. Gornitz, V. Sea-level rise: a review of recent past and near-future trends. Earth Surf. Process. Landf. 20, 7-20 (1995).

20. Huntington, T. G. Can we dismiss the effect of changes in land based water storage on sea level rise? Hydrol. Process. 22, 717-723 (2008).

21. IHP-VI Non-Renewable Groundwater Resources: A Guidebook on Socially-sustainable Management for Water-policy Makers Series on Groundwater No. 10 (UNESCO, 2006).

22. Famiglietti, J. S. The global groundwater crisis. Nature Clim. Change 4 945-948 (2014)

23. Rodell, M., Velicogna, I. \& Famiglietti, J. S. Satellite based estimates of groundwater depletion in India. Nature 460, 999-1002 (2009).

24. Tiwari, V. M., Wahr, J. \& Swenson, S. Dwindling groundwater resources in northern India, from satellite gravity observations. Geophys. Res. Lett. 36, L18401 (2009).

25. Famiglietti, J. S. et al. Satellites measure recent rates of groundwater depletion in California's Central Valley. Geophys. Res. Lett. 38, L03403 (2011).

26. Richey, A. S. et al. Quantifying renewable groundwater stress with GRACE. Wat. Resour. Res. 51, 5217-5238 (2015).

27. DeAngelis, A. et al. Evidence of enhanced precipitation due to irrigation over the Great Plains of the United States. J. Geophys. Res. 115, D15115 (2010).

28. Kustu, M. D., Fan, Y. \& Robock, A. Large-scale water cycle perturbation from irrigation in the High Plains: a synthesis of observed streamflow changes. J. Hydrol. 390, 222-224 (2010).

29. Lo, M.-H. \& Famiglietti, J. S. Irrigation in California's Central Valley strengthens the southwestern U. S. water cycle. Geophys. Res. Lett. 40, 301-306 (2013)

30. Chao, B. F., Wu, Y. H. \& Li, Y. S. Impact of artificial reservoir water impoundment on global sea level. Science 320, 212-214 (2008).

\section{Acknowledgements}

Y.W. is supported by Japan Society for the Promotion of Science (JSPS) Oversea Research Fellowship (grant no. JSPS-2014-878). M.-H.L. is supported by grants MOST-104-2923-M-002-002-MY4 and MOST-100-2119-M-001-029-MY5 to National Taiwan University. J.T.R. and J.S.F. are supported by NASA grants from the GRACE Science Team, the Sea Level Program and by Water Initiative at the Jet Propulsion Laboratory, California Institute of Technology. M.-H.L., J.T.R. and J.S.F. are also supported by a grant from the University of California Office of the President, Multicampus Research Programs and Initiatives.

\section{Author contributions}

Y.W., M.-H.L. and P.J.-F.Y. performed background research and designed the study with contributions from the other co-authors. M.-H.L., Y.-H.T., R.-J.W. and Y.W. prepared the data and conducted the model simulation. Y.W., M.-H.L. and P.J.-F.Y. prepared the manuscript. All authors discussed the results and commented on the manuscript. 


\section{Methods}

Globally, around half of pumped groundwater for irrigation is used by plants, whereas the remainder possibly flows to the ocean as runoff causing SLR; evaporates into the atmosphere increasing water vapour content; returns back to the aquifers through groundwater recharge; or affects the atmospheric circulation owing to surface energy modifications and changes the precipitation intensity or pattern locally, regionally and globally $y^{9,27,28}$. In this study, we used the state-of-the-art fully coupled NCAR CESM ${ }^{11}$ version 1.0.3 to simulate the fate of water pumped from groundwater and calculate the relative proportion of GWD to the sea-level changes. Here, we introduce the model set-up and, in particular, the atmospheric and land components of the CESM. We also evaluate the land water storage simulations from CMIP5 and the performance of CESM in the models.

Model set-up. Numerical experiments were conducted using CESM to understand how groundwater withdrawal affects land-atmosphere interactions and the land water and sea-level budgets. The experiments were performed in a fully coupled land-ocean-atmosphere configuration of the CESM, including the Community Atmosphere Model version 4 (CAM4) and the Community Land Model Version 4 (CLM4), which simulates land hydrological processes. Both CAM4 and CLM4 are explained separately in following sections. The ocean component of CESM is the Parallel Ocean Program version 2 (POP2), which is a hydrostatic, free-surface, primitive-equation model formulated on a curvilinear orthogonal grid ${ }^{31}$. The nominal $1^{\circ}$ horizontal resolution version of the ocean component is used with 60 vertical levels. The sea-ice model is the updated Los Alamos Sea Ice Model version 4 (CICE4) and shares the same horizontal grid as POP2 ${ }^{32}$. It is a dynamic-thermodynamic model that includes a subgrid-scale ice thickness distribution. Two fully coupled (atmosphere-land-ocean-ice) experiments conducted with CESM are presented here: the first experiment is a control run (CTR) without groundwater pumping and the second is a GWD run. In the GWD run, an extra anthropogenic groundwater pumping flux from 1900-1999 based on updated and corrected groundwater pumping ${ }^{7}$ is represented in the Community Land Model 4 (CLM4) ${ }^{12}$ of the CESM. Both simulations were branched from a pre-industrial (1850-1999) control experiment and integrated for 150 years. In order to remove the effects of uncertain initial conditions, the first 50 simulated years (1850-1899) are treated as spin-up, and the latter 100 years were used for the analysis.

Introduction of CAM4. CAM4 is conducted with a horizontal model resolution of $1.9^{\circ} \times 2.5^{\circ}$ and with 26 vertical hybrid coordinate levels. The default atmospheric component of CESM is based on the finite volume dynamic core of CAM4 described in the dynamic core of CAM4 ${ }^{33}$. The model physics are updated to improve model simulation by including the effects of deep convection in the momentum equation and using a dilute approximation in the plume calculation. The trade wind biases in the eastern ocean basins are reduced owing to the new convective momentum transport. The convective dilute plume calculation in deep convection schemes also mitigates the tropical dry biases over the middle troposphere and reduces the monsoon precipitation biases over the Arabian Peninsula. For the details of these changes, the reader is referred to the above study ${ }^{33}$ and the references therein.

Introduction of CLM4. The land model used in this study is the CLM4 $4^{12,34}$ with the representation of an unconfined aquifer mode ${ }^{35}$ and the SIMTOP (simple TOPMODEL-based) runoff generation scheme ${ }^{36}$. In the previous version of the CLM (CLM 3.0), the boundary condition at the bottom of soil layers was universally prescribed as the following gravity drainage flux $q_{\mathrm{g}}$ (that is, the drainage is equal to the unsaturated hydraulic conductivity):

$$
q_{\mathrm{g}}=-k \frac{\partial \Psi_{\mathrm{g}}}{\partial z}=-k \frac{\partial(-z)}{\partial z}=k
$$

where $q\left(\mathrm{~mm} \mathrm{~s}^{-1}\right)$ is the soil water flux (negative upwards) along the vertical $z$ direction, $k\left(\mathrm{~mm} \mathrm{~s}^{-1}\right)$ is the hydraulic conductivity, and $\Psi(\mathrm{mm})$ is the hydraulic potential. The hydraulic potential can be separated into soil water potential $\Psi_{\mathrm{m}}$ and gravitational potential $\Psi_{\mathrm{g}}$. Because the reference level is at the soil surface, $\Psi_{\mathrm{g}}$ is equal to the depth $(-z)$.

Compared to the soil water flux computations in CLM3, the most significant modification of adding an unconfined aquifer model in CLM4 is the availability of an extra source of groundwater for transpiration use and baseflow generation. The water table is dynamically linked to soil moisture through groundwater recharge (that is, soil drainage flux) and capillary rise at the interface of soil layers and the groundwater water table. The (upward) capillary flux $\left(q_{\mathrm{m}}\right)$ can be described as follows:

$$
q_{\mathrm{m}}=-k \frac{\partial \Psi_{\mathrm{m}}}{\partial z}
$$

For more detailed descriptions of CLM4, we refer to four studies ${ }^{12,34-36}$. With the groundwater representation, CLM4 can simulate the impacts of groundwater withdrawals on the atmospheric processes as in this study. The aquifer system in CLM4 is a combination of unconfined and confined aquifers (that is, aquifers that are overlain by a low permeability, confining layer, often made up of clay). Without sufficient information on global hydrogeology, it is assumed here that groundwater withdrawals are equally distributed between both types of aquifer. Because only the unconfined aquifer is represented in CLM4, withdrawals from the confined aquifers are assumed to pump from a hypothetical water store (the same configuration as in a previous study ${ }^{29}$ ). Pumping from unconfined aquifer layers is taken from the saturated zone of the soil. For simplicity, groundwater withdrawals are evenly distributed in each time step throughout the entire simulation period, as conducted in previous studies ${ }^{29,37}$. The applied irrigation water is treated as precipitation-that is, the available water that infiltrates into the soil and partly goes to runoff.

Calculation of GWD contribution to sea-level changes. We calculate the portion of GWD on the sea-level changes by integrating the oceanic precipitation, evaporation and (terrestrial) runoff from the water budget equation (precipitation plus runoff minus evaporation) from 1900 to 1999 (Table 1). In order to account for the model uncertainty, we also conducted the GWD run with upper and lower groundwater pumping estimates using the standard deviation of the 100 realizations of groundwater pumping estimates ${ }^{7}$ (Fig. 2). Overall, comparing the runs with and without GWD over the period 1900-1999 enables us to detect long-term changes in the global land and ocean water budget that quantify the net flux to the ocean due to groundwater contribution to the sea-level budget, showing the relative fraction of GWD that ends up in the ocean is approximately $80 \%$.

Evaluation of performance of CAM4 and CLM4. A previous study ${ }^{38}$ conducted a comprehensive evaluation on the performance of Community Climate System Model version 4 (CCSM4), the previous version of CESM1.0.3 used here (also including CAM4 and CLM4). They found that the modification in the atmospheric deep convection schemes leads to a more realistic frequency distribution of the El Niño-Southern Oscillation variability, the Madden-Julian oscillation, and the frequency distribution of tropical precipitation compared to CCSM3. Improvements in the simulation of the Gulf Stream path and the Meridional Overturning Circulation over the North Atlantic Ocean are also observed with a new overflow parameterization in the ocean component of CCSM4.

In addition, after incorporating a simple unconfined groundwater mode ${ }^{36}$ in CLM4, the simulated terrestrial water storage shows a better seasonal cycle, especially in the tropics ${ }^{36}$. The terrestrial water cycle is also improved with better latent heat fluxes and river runoff. One study ${ }^{12}$ indicated that total runoff simulated by CLM4 is increased by approximately $9 \%$ over CLM3.5, and is also closer to the near observed annual global discharge to the ocean $s^{39}$.

Supplementary Fig. 1 presents the comparison between the annual global-average terrestrial water storage changes and the net fluxes of $P-E-R$ (precipitation minus evaporation and runoff) simulated by 19 global climate models (listed in Supplementary Table 1) participating in the Coupled Model Intercomparison Project Phase 5 (CMIP5) archives ${ }^{40}$. The one-to-one line in Supplementary Fig. 1 accords with the conservation of the terrestrial water cycle. This figure clearly shows the good performance of NCAR (CESM) models (highlighted in red, green, purple, green, and orange) on the simulated global terrestrial water budget compared to the other CMIP5 models.

We further use GRACE data to evaluate the simulated seasonal cycle of terrestrial water storage in the CMIP5 models. Supplementary Fig. 2 shows the normalized Taylor diagram, which presents a comparison of the GRACE observations with the CMIP5 model simulations for the seasonal cycle of global land water storage. The NCAR models are labelled with numbers from one to five, and red dots indicate the rest of CMIP5 models listed in Supplementary Table 1. The Taylor diagram can provide a statistical perspective of how well patterns match with observations. It reveals both the relationship between GRACE and the model simulations (the radial line), and the variance between the two time series (standard deviations on the $x$ and $y$ axes). Based on the Taylor diagram, the figure shows that the NCAR models have reasonable simulations of the seasonal cycle.

Another study ${ }^{41}$ specifically indicated that CCSM4 is suitable to study the roles of land processes in climate and climate change; thus, this unique earth system model was used in this study to explore how groundwater withdrawal affects the global sea-level budgets (see also Supplementary Information).

Estimation of global groundwater withdrawals (pumping). We retrieve country-based groundwater abstraction rates for the benchmark year 2000 from the IGRAC GGIS database (http://www.un-igrac.org). To estimate country-based groundwater abstraction for the years 1900-1999, we then assume this to change proportionally to country total water demand (see a previous study ${ }^{6,7}$ for validation of this assumption). Next, we calculate grid-based estimates of groundwater abstraction by downscaling country-based groundwater abstraction rates, using the difference between surface water availability and total water demand as a proxy (that is, pumping locations $=$ demands $>$ availability). We estimate monthly surface water availability from 1900 to 1999 simulations with the global 
hydrological model PCR-GLOBWB ${ }^{6,7}$. We estimate groundwater recharge from PCR-GLOBWB, although additional recharge from irrigation practices was also accounted for. We calculate monthly total water demands as the sum of domestic, industrial and irrigation water demand ${ }^{42}$. We first obtain country statistics on GDP (Gross Domestic Product), population numbers and electricity and energy consumption, then downscale these to a grid by using available gridded data to estimate industrial and domestic water demand, considering economic and technological advancement. We downscale country irrigated areas to a grid and simulate crop-specific evaporative demand, then combine the results with country-specific efficiency factors to estimate irrigation water demand. The difference between grid-based groundwater recharge and groundwater abstraction then yields an estimate of groundwater depletion (GWD). Finally, we compare estimated depletion rates for the year 2000 with independent regional estimates for the period 1990-2010 to remediate increased capture by decreased discharge and increased recharge from surface water by a general multiplicative correction factor ${ }^{7}$.

Uncertainty in global groundwater recharge, pumping, and depletion. We identify an uncertainty model for groundwater recharge by comparing the PCR-GLOBWB recharge estimate with an independent estimate and the PCR-GLOBWB streamflow estimates with the GRDC observed streamflow data ${ }^{6}$ For groundwater abstraction, we compared country-based abstraction rates used in this study with those reported in the FAO AQUASTAT database

(http://www.fao.org/nr/water/aquastat/main/index.stm). Using these uncertainty models we perform a Monte Carlo simulation, generating 100 random maps of groundwater recharge and 100 random maps of groundwater abstraction. From the 10,000 combinations we estimate standard deviations for cell-based, country-based and global groundwater depletion. We apply this procedure for each year (1900-1999).

Extrapolation of other sources (dams, wetlands, deforestation, endorheic basins). We obtain data on reservoir impoundment, including additional storage in surrounding groundwater (seepage) ${ }^{30}$. As this data set covers only the period 1900-2007, we updated the effects of the Three Gorges dam and other recent dams based on the ICOLD database (http://www.icold-cigb.org/GB/World_register/ world_register.asp). To extrapolate into 2010, we plot the cumulative reservoir volume stored behind dams and fit a smooth function. Rates for 2010 are subsequently obtained by taking derivatives. We assume deforestation to continue at a constant rate ${ }^{7}$. Wetland loss for the US is extrapolated to that of the world using three global wetland data sets, assuming wetland loss to be proportional to wetland area. Storage loss from endorheic basins (mostly the Aral Sea) is estimated from an earlier work ${ }^{7,13}$, but updated with a recent storage change of the northern basin of the Aral Sea.

\section{References}

31. Danabasoglu, G. et al. The CCSM4 Ocean Component. J. Clim. 25, 1361-1389 (2012).

32. Hunke, E. C. \& Lipscomb, W. H. CICE: The Los Alamos Sea Ice Model. Documentation and Software User's Manual Version 4.0 LA-CC-06-012 (Los Alamos National Laboratory T-3 Fluid Dynamics Group, 2008).

33. Neale, R. B. et al. The mean climate of the Community Atmosphere Model (CAM4) in forced SST and fully coupled experiments. J. Clim. 26, 5150-5168 (2013).

34. Oleson, K. W. et al. Improvements to the Community Land Model and their impact on the hydrological cycle. J. Geophys. Res. 113, G01021 (2008).

35. Niu, G.-Y., Yang, Z.-L., Dickinson, R. E. \& Gulden, L. E. A simple TOPMODEL-based runoff parameterization (SIMTOP) for use in global climate models. J. Geophys. Res. 110, D21106 (2005).

36. Niu, G.-Y., Yang, Z.-L., Dickinson, R. E., Gulden, L. E. \& Su, H. Development of a simple groundwater model for use in climate models and evaluation with Gravity Recovery and Climate Experiment data. J. Geophys. Res. 112, D07103 (2007).

37. Sacks, W. J., Cook, B. I., Buenning, N., Levis, S. \& Helkowski, J. H. Effects of global irrigation on the near-surface climate. Clim. Dynam. 33, 159-175 (2009).

38. Gent, P. R. et al. The Community Climate System Model version 4. J. Clim. 24, 4973-4991 (2011)

39. Fekete, B. M., Vorosmarty, C. J. \& Grabs, W. High-resolution fields of global runoff combining observed river discharge and simulated water balances. Glob. Biogeochem. Cycles 16(3), 15-1-15-10 (2002).

40. Taylor, K. E., Stouffer, R. J. \& Meehl, G. A. An overview of CMIP5 and the experiment design. Bull. Am. Meteorol. Soc. 93, 485-498 (2012).

41. Lawrence, D. M. et al. The CCSM4 land simulation, 1850-2005: assessment of surface climate and new capabilities. J. Clim. 25, 2240-2260 (2012).

42. Wada, Y., Van Beek, L. P. H. \& Bierkens, M. F. P. Modelling global water stress of the recent past: on the relative importance of trends in water demand and climate variability. Hydrol. Earth Syst. Sci. 15, 3785-3808 (2011). 